\title{
QUALITY CONTROL ANALYSIS TO REDUCE THE NUMBER OF DEFECTS IN THE PACKAGING OF PG KREMBOONG SUGAR PRODUCTS USING SEVEN TOOLS METHOD
}

\author{
Yoniv Erdhianto \\ Industrial Engineering Department, Industrial Tehnology of Faculty - Institut Teknologi Adhi Tama Surabaya \\ email: yoniv@itats.ac.id
}

\begin{abstract}
Quality control is an activity that must be carried out by a company so that the products produced are in accordance with the standards set by the company in order to meet customer satisfaction. This research was conducted in order to obtain the results of the quality control analysis which then the results of the analysis will be used as an effort to reduce the number of defects in product packaging in the future at PG Kremboong. This research in solving the problem using the seven tools method. This seven tools method uses 7 quality control tools, namely Check Sheet, Control Chart, Cause and Effect Diagram, Pareto Diagram, Histogram, Scatter Diagram and Stratification so that a quantitative measurement is produced that shows the extent to which management objectives have been achieved. From the analysis using the seven tools, the defects in granulated sugar with $50 \mathrm{~kg}$ packages were produced, namely, less light prints (146), torn packages (299), dirty packages (224) and loose seams (200). The defect with torn packaging is the most dominant type of defect. Improvement steps to reduce the number of defects in sugar packaging in the future are carried out on 5 factors, namely humans, methods, machines, materials and the environment based on a comparison between the causes of the problem and the standards applicable in the company.
\end{abstract}

Keywords: Quality Controll, sevent tool, Packaging.

\section{INTRODUCTION}

Quality is a characteristic of a product in its ability to meet predetermined needs and is latent (Heizer et al, 2015). Meanwhile, Fuad et al (2006), quality is the advantage that the product has. Quality in the view of consumers is something that has its own scope that is different from the quality in the view of the manufacturer when issuing a product that is commonly knownfor its true quality. Quality control is a management tool to ensure quality, because basically no two products produced by a production process are the same, it cannot be avoided that there are variations. Experimental designs can be used in conjunction with statistical process control to minimize process variability and produce production that is ultimately defect free (Yetti, 2016). Statistical testing is needed to solve problems like this, in quality control these statistical techniques are applied to check and test data to determine standards and check the suitability of products to achieve maximum manufacturing operations, and usually result in lower quality costs and increase the level of competitive position.

Kremboong Sugar Factory is one of the sugar companies under the supervision of PT Perkebunan Nusantara $X$ which is located in Krembung Village, Krembung District, Sidoarjo Regency, East Java. This study identifies the types of defects and factors that cause defects in granulated sugar product packaging which will then be used as a basis for taking corrective steps to reduce the number of defects in sugar packaging in the future.

This research in solving the problem using the seven tools method. The problems discussed were the identification of the number of defects in sugar packaging and the proposed improvements in an effort to reduce the number of defects in sugar packaging at the PG Kremboong Sugar Bagging (Warehouse) department. The data taken in this study are the daily sugar production output and defect data in granulated sugar packaging. The collection of data on the number of production and defects in granulated sugar products is carried 
out daily, which in one day (24 hours) there are 3 work shifts. Data on defects in products is obtained based on reports from operators for each work shift which are then added up and checked for correctness to the relevant supervisor.

This research in solving the problem using the seven tools method. The problems discussed were the identification of the number of defects in sugar packaging and the proposed improvements in an effort to reduce the number of defects in sugar packaging at the PG Kremboong Sugar Bagging (Warehouse) department. The data taken in this study are the daily sugar production output and defect data in granulated sugar packaging. The collection of data on the number of production and defects in granulated sugar products is carried out daily, which in one day (24 hours) there are 3 work shifts. Data on defects in products is obtained based on reports from operators for each work shift which are then added up and checked for correctness to the relevant supervisor.

\section{Research Methods}

Basically, seven tools are used to solve problems that occur in the production process. Seven tools are 7 tools used to support quality control. as mentioned also by Heizer and Render in his book Operations Management (2006: 263-268), including:

(a) Check Sheet

A check sheet is a simple designed sheet containing a list of things needed for data recording purposes so that users can collect data easily, systematically, and regularly when the data appears at the location of the incident.

(b) Scatter Diagram

A scatter diagram is a graph showing a pair of numerical data in a Cartesian coordinate system, with one variable on each axis, to see the relationship between the two variables. If the two variables are correlated, the coordinate points will fall along the line or curve.

(c) Fishbone Diagram

Fishbone diagrams (fishbone diagrams) are often called Ishikawa diagrams or cause and effect diagrams (cause-and-effect diagrams). Fishbone diagram is a tool for identifying various potential causes of an effect or problem, and analyzing the problem through a brainstorming session.

(d) Pareto Chart

Pareto chart (pareto chart) is a chart that contains a bar graph and line graph, a bar chart shows the classification and value of data, while a line chart represents the cumulative total data. The pareto chart principle is in accordance with Pareto law which states that a group always has the smallest percentage $(20 \%)$ of value or has the greatest impact $(80 \%)$.

(e) Flow charts

Flow charts are a tool for visualizing the process of completing a task in a step-by-step manner for the purposes of analysis, discussion, communication, and can help us find areas of improvement in the process (Tjiptono, Fandy \& Anastasia Diana, 2003)

(f) Histogram

A histogram is a bar graph-like tool used to show the distribution of frequencies. A frequency distribution shows how often each different value in a data set occurs. The data in the histogram is divided into classes, the observed value of each class is shown on the $\mathrm{X}$ axis.

(g) Control Chart

Control chart or control chart is a map that is used to study how the process changes over time. The data are plotted in chronological order. The control chart always consists of three horizontal lines, namely: Center line, a line that shows the mean or average value of the quality characteristics plotted on the control chart. Upper control limit (UCL), a line above the center line that shows the upper control limit. Lower control limit (LCL), a line under the center line that shows the lower control limit 


\section{TiBuana}

Journal of applied Industrial Engineering-University of PGRI AdiBuana

DOI : https://doi.org/10.36456/tibuana.4.01.3174.28-35

(Tjiptono, Fandy \& Anastasia Diana, 2003: 195).

\section{Results and Discussion}

Check Sheet The check sheet is used to calculate the percentage of defects in granulated sugar products with $50 \mathrm{Kg}$ packs. The data were obtained from observations from the period July to September 2018. The following are the results of processing using a check sheet:

Table 1. Check sheet for $50 \mathrm{~kg}$ Packaged Sugar Products

\begin{tabular}{|c|c|c|c|c|c|c|c|}
\hline \multirow[b]{2}{*}{ Data } & \multirow[b]{2}{*}{ Tanggal } & \multirow{2}{*}{$\begin{array}{l}\text { Jumlah } \\
\text { Produksi }\end{array}$} & \multicolumn{4}{|c|}{ Jenis Cacat } & \multirow[b]{2}{*}{ Jumlah Cacat } \\
\hline & & & $\begin{array}{c}\text { Cetakan } \\
\text { Kurang Terang }\end{array}$ & $\begin{array}{l}\text { Kemasan } \\
\text { Sobek }\end{array}$ & Kemasan Kotor & $\begin{array}{l}\text { Jahitan } \\
\text { Terlepas }\end{array}$ & \\
\hline 1 & $19 / 07 / 2018$ & 4080 & $\mathrm{II}=2$ & $\mathrm{THK}=5$ & III = 3 & $I=1$ & 11 \\
\hline 2 & $20 / 07 / 2018$ & 4120 & $I=1$ & ЖЖ НЦI I = 11 & IINII = 7 & IIIN= 5 & 24 \\
\hline 3 & $21 / 07 / 2018$ & 3940 & $\mathrm{IIII}=4$ & IIHII = $=7$ & IIN $=6$ & IIKI $=6$ & 23 \\
\hline 4 & $23 / 07 / 2018$ & 4000 & $\mathrm{IHI}=5$ & $\mathrm{HH} I=6$ & $\mathrm{I}=1$ & IIII $=5$ & 17 \\
\hline 5 & $24 / 07 / 2018$ & 4120 & $\mathrm{II}=2$ & IIH I = 6 & $\Pi 1 \mathrm{H}=5$ & $\mathrm{ITH}=5$ & 18 \\
\hline 6 & $25 / 07 / 2018$ & 3900 & $\mathrm{III}=3$ & THA IIII = 9 & THI II $=7$ & $\mathrm{IIII}=4$ & 23 \\
\hline 7 & $26 / 07 / 2018$ & 4200 & $\mathrm{III}=3$ & HUII = 7 & IIII = 4 & $\mathrm{TH}=5$ & 19 \\
\hline 8 & $27 / 07 / 2018$ & 3920 & $\mathrm{I}=1$ & $\mathrm{ITH}=6$ & $\mathrm{III}=3$ & $\mathrm{II}=2$ & 12 \\
\hline 9 & $28 / 07 / 2018$ & 3460 & $\mathrm{I}=1$ & THKI $=6$ & $\mathrm{IHN}=6$ & $\mathrm{HHI} \mathrm{I}=6$ & 19 \\
\hline 10 & $30 / 07 / 2018$ & 4400 & $\mathrm{IIII}=4$ & $\mathrm{III}=3$ & $\mathrm{IHN}=6$ & IIII = 4 & 17 \\
\hline 11 & $31 / 07 / 2018$ & 4200 & $\mathrm{II}=2$ & THLIIII $=9$ & $\Pi 11+=5$ & $\mathrm{HH}=6$ & 22 \\
\hline 12 & 01/08/2018 & 4200 & $\mathrm{II}=2$ & $\mathrm{TH}=5$ & $\mathrm{IIIN}=6$ & $\mathrm{TH}=5$ & 18 \\
\hline 13 & $02 / 08 / 2018$ & 4200 & $\mathrm{II}=2$ & IIHNIII $=9$ & IIIN $=6$ & IIII = 4 & 21 \\
\hline 14 & 03/08/2018 & 4160 & $\mathrm{II}=2$ & $\mathrm{IIII}=5$ & $\mathrm{IIII}=4$ & $\mathrm{III}=3$ & 14 \\
\hline 15 & $04 / 08 / 2018$ & 4420 & $\mathrm{III}=3$ & IIIHIII = 9 & $\mathrm{IIIHH}=7$ & $\mathrm{III}=3$ & 22 \\
\hline 16 & $06 / 08 / 2018$ & 4060 & $\mathrm{I}=1$ & HWL IIII = 9 & $\mathrm{II}=2$ & $\mathrm{IIII}=4$ & 16 \\
\hline 17 & 07/08/2018 & 4340 & $\mathrm{I}=1$ & IHKII = 7 & $\Pi \mathrm{TH}=5$ & $\mathrm{II}=2$ & 15 \\
\hline 18 & 08/08/2018 & 4180 & $\mathrm{TH}=5$ & IIHTHL $=10$ & $\mathrm{II}=2$ & $\mathrm{III}=3$ & 20 \\
\hline 19 & 09/08/2018 & 4500 & $\mathrm{III}=3$ & IIII = 4 & $\mathrm{III}=3$ & $\mathrm{III}=3$ & 13 \\
\hline 20 & $10 / 08 / 2018$ & 2300 & $\mathrm{II}=2$ & $\mathrm{II}=2$ & $\mathrm{III}=3$ & $\mathrm{HH}=5$ & 12 \\
\hline 21 & $11 / 08 / 2018$ & 4720 & $\mathrm{II}=2$ & $\mathrm{II}=2$ & $\mathrm{II}=2$ & $\mathrm{III}=3$ & 9 \\
\hline 22 & $13 / 08 / 2018$ & 4000 & $\mathrm{II}=2$ & $\mathrm{III}=3$ & $\mathrm{IIII}=4$ & $\mathrm{THK}=5$ & 14 \\
\hline 23 & $14 / 08 / 2018$ & 4440 & $\mathrm{I}=1$ & IIII = 4 & $\mathrm{III}=3$ & $\mathrm{HH}=5$ & 13 \\
\hline 24 & $15 / 08 / 2018$ & 4800 & $\mathrm{III}=3$ & $\mathrm{THN}=6$ & $\mathrm{IHN}=6$ & $\mathrm{I}=1$ & 16 \\
\hline 25 & $16 / 08 / 2018$ & 4720 & $\mathrm{III}=3$ & $\mathrm{IHN}=6$ & $\mathrm{II}=2$ & THLII $=7$ & 18 \\
\hline 26 & $18 / 08 / 2018$ & 4700 & $\mathrm{III}=3$ & $\mathrm{THK}=5$ & $\mathrm{IIII}=4$ & $\mathrm{IIII}=4$ & 16 \\
\hline 27 & $20 / 08 / 2018$ & 4420 & $\mathrm{II}=2$ & $\mathrm{IIII}=4$ & $\mathrm{III}=3$ & $\mathrm{IIII}=4$ & 13 \\
\hline 28 & $21 / 08 / 2018$ & 4440 & $\mathrm{III}=3$ & IIIN $=6$ & $\mathrm{IIII}=4$ & $\mathrm{HH}=5$ & 18 \\
\hline 29 & $23 / 08 / 2018$ & 4600 & $\mathrm{IIII}=4$ & HW II = 7 & $\mathrm{HH}=5$ & $\mathrm{HH} \mathrm{I}=6$ & 22 \\
\hline 30 & $24 / 08 / 2018$ & 4500 & IIII = 4 & $\mathrm{III}=3$ & $\operatorname{INK}=5$ & $\mathrm{THL}=6$ & 18 \\
\hline 31 & $25 / 08 / 2018$ & 3240 & $\mathrm{II}=2$ & $\mathrm{II}=2$ & $\mathrm{IIII}=4$ & IIII = 4 & 12 \\
\hline 32 & $27 / 08 / 2018$ & 3180 & $\mathrm{I}=1$ & $\mathrm{II}=2$ & $\mathrm{III}=3$ & $\mathrm{II}=2$ & 8 \\
\hline 33 & $28 / 08 / 2018$ & 3300 & $\mathrm{I}=1$ & $\mathrm{III}=3$ & $\mathrm{IIN}=6$ & $\mathrm{II}=2$ & 12 \\
\hline 34 & $29 / 08 / 2018$ & 4200 & $\mathrm{I}=1$ & $\mathrm{IIII}=4$ & $\mathrm{III}=3$ & $\mathrm{II}=2$ & 10 \\
\hline 35 & $30 / 08 / 2018$ & 3700 & $\mathrm{II}=2$ & $\mathrm{IIII}=4$ & $\mathrm{IIIN}=6$ & $\mathrm{I}=1$ & 13 \\
\hline 36 & 01/09/2018 & 4300 & $\mathrm{II}=2$ & $\mathrm{IIII}=4$ & $\mathrm{IH}=5$ & $\mathrm{III}=3$ & 14 \\
\hline 37 & 03/09/2018 & 3820 & $\mathrm{III}=3$ & $\mathrm{IIII}=4$ & $\mathrm{III}=3$ & $\mathrm{THKI}=6$ & 16 \\
\hline 38 & $04 / 09 / 2018$ & 3800 & $\mathrm{HI}=5$ & $\mathrm{II}=2$ & $\mathrm{III}=3$ & $\mathrm{IIII}=4$ & 14 \\
\hline 39 & $05 / 09 / 2018$ & 4120 & $\mathrm{II}=2$ & $\mathrm{THH} I I=7$ & $\mathrm{I}=1$ & $\mathrm{III}=3$ & 13 \\
\hline 40 & 06/09/2018 & 4200 & IIII = 4 & IIII = 4 & $\mathrm{I}=1$ & $\mathrm{II}=2$ & 11 \\
\hline 41 & 07/09/2018 & 4340 & $\mathrm{II}=2$ & $\mathrm{IIII}=4$ & $\mathrm{III}=3$ & $\mathrm{III}=3$ & 12 \\
\hline 42 & 08/09/2018 & 4340 & $\mathrm{II}=2$ & $\mathrm{IIII}=4$ & $\mathrm{II}=2$ & $\mathrm{II}=2$ & 10 \\
\hline 43 & $10 / 09 / 2018$ & 4300 & $\mathrm{I}=1$ & $\mathrm{IIII}=4$ & $\mathrm{IIII}=4$ & $\mathrm{I}=1$ & 10 \\
\hline 44 & $12 / 09 / 2018$ & 4060 & $=0$ & $\mathrm{III}=3$ & IIII $=5$ & $\mathrm{I}=1$ & 9 \\
\hline 45 & $13 / 09 / 2018$ & 4120 & $\mathrm{II}=2$ & $\mathrm{III}=3$ & $\mathrm{IIII}=4$ & $\mathrm{III}=3$ & 12 \\
\hline 46 & $14 / 09 / 2018$ & 4140 & $\mathrm{I}=1$ & $\mathrm{IHN}=6$ & $\mathrm{IIII}=4$ & $\mathrm{II}=2$ & 13 \\
\hline 47 & $15 / 09 / 2018$ & 3700 & $\mathrm{III}=3$ & $\mathrm{IHH}=5$ & $\mathrm{III}=3$ & $\mathrm{IIII}=4$ & 15 \\
\hline 48 & $17 / 09 / 2018$ & 4040 & $\mathrm{II}=2$ & IIII = 4 & $\mathrm{II}=2$ & $\mathrm{III}=3$ & 11 \\
\hline 49 & $18 / 09 / 2018$ & 4200 & $\mathrm{III}=3$ & $\mathrm{HWI}=6$ & $\mathrm{III}=3$ & $\mathrm{II}=2$ & 14 \\
\hline 50 & $19 / 09 / 2018$ & 4240 & $\mathrm{II}=2$ & $\mathrm{IIII}=4$ & $\mathrm{THH}=5$ & $\mathrm{II}=2$ & 13 \\
\hline 51 & $20 / 09 / 2018$ & 4040 & $\mathrm{I}=1$ & $\mathrm{III}=3$ & $\mathrm{IHK}=5$ & $\mathrm{II}=2$ & 11 \\
\hline
\end{tabular}




\section{TiBuana}

Journal of applied Industrial Engineering-University of PGRI AdiBuana

DOI : https://doi.org/10.36456/tibuana.4.01.3174.28-35

Table 2. Check sheet for $50 \mathrm{~kg}$ Packaged Sugar Products

\begin{tabular}{|c|c|c|c|c|c|c|c|}
\hline \multirow[b]{2}{*}{ Data } & \multirow[b]{2}{*}{ Tanggal } & \multirow[b]{2}{*}{$\begin{array}{l}\text { Jumlah } \\
\text { Produksi }\end{array}$} & \multicolumn{4}{|c|}{ Jenis Cacat } & \multirow[b]{2}{*}{ Jumlah Cacat } \\
\hline & & & $\begin{array}{c}\text { Cetakan } \\
\text { Kurang Terang }\end{array}$ & $\begin{array}{c}\text { Kemasan } \\
\text { Sobek }\end{array}$ & Kemasan Kotor & $\begin{array}{c}\text { Jahitan } \\
\text { Terlepas }\end{array}$ & \\
\hline 52 & $21 / 09 / 2018$ & 4540 & $\mathrm{II}=2$ & $\mathrm{II}=2$ & $\mathrm{III}=3$ & $\mathrm{II}=2$ & 9 \\
\hline 53 & $22 / 09 / 2018$ & 4420 & $\mathrm{IIII}=4$ & $\mathrm{IIII}=4$ & $\mathrm{IIII}=4$ & $\mathrm{I}=1$ & 13 \\
\hline 54 & $24 / 09 / 2018$ & 4200 & $\mathrm{IH}=5$ & $\mathrm{HII}=5$ & $\mathrm{II}=2$ & $\mathrm{I}=1$ & 13 \\
\hline 55 & $25 / 09 / 2018$ & 4280 & $\mathrm{III}=3$ & $I=2$ & $\mathrm{II}=2$ & $\mathrm{IIII}=4$ & 11 \\
\hline 56 & $26 / 09 / 2018$ & 4040 & $\mathrm{II}=2$ & $\mathrm{IIII}=4$ & $\mathrm{I}=1$ & $\mathrm{III}=3$ & 10 \\
\hline 57 & $27 / 09 / 2018$ & 3920 & $\mathrm{III}=3$ & $\mathrm{HWI} \mathrm{I}=6$ & $\mathrm{II}=2$ & $\mathrm{III}=3$ & 14 \\
\hline 58 & $28 / 09 / 2018$ & 4240 & $\Pi \mathrm{IH}=5$ & ЖUI I = 6 & $\mathrm{III}=3$ & $\mathrm{III}=3$ & 17 \\
\hline 59 & 29/09/2018 & 3920 & IIII = 4 & WII II = 7 & $\mathrm{III}=3$ & $\mathrm{II}=2$ & 16 \\
\hline
\end{tabular}

a. Histogram

The histogram is used to show the most dominant type of defect in granulated sugar products with a 50 $\mathrm{Kg}$ package. The following is the result of processing using a histogram:

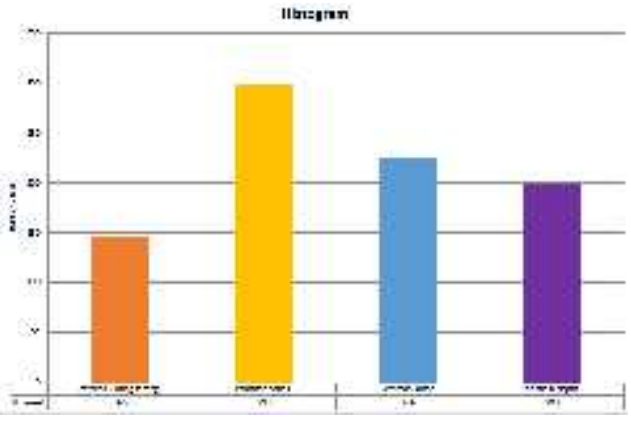

Figure 1. Histogram

b. The Pareto Diagram

Pareto Diagram is used to determine the order of the types of defects that occur based on the order of the number of events that occur in granulated sugar products with $50 \mathrm{Kg}$ packs. The following is the result of processing using the Pareto diagram: Table 2. Number of Defects and Percentage of Defects in $50 \mathrm{Kg}$ Packaged Sugar.

Table 2. Number of Defects

\begin{tabular}{ccccc}
\hline Code & Defect & $\begin{array}{c}\text { Number of } \\
\text { Defect } \\
(\text { Unit })\end{array}$ & $\begin{array}{c}\text { Procentage } \\
\text { of Defect } \\
(\%)\end{array}$ & $\begin{array}{c}\text { Cumulative } \\
\text { Procentage } \\
(\%)\end{array}$ \\
\hline 1 & $\begin{array}{c}\text { Torn } \\
\text { Packaging } \\
\text { Dirty } \\
\text { Packaging } \\
\text { Stitches } \\
\text { Apart }\end{array}$ & 299 & 34,41 & 34,41 \\
4 & $\begin{array}{c}\text { Less Bright } \\
\text { Print }\end{array}$ & 146 & 25,78 & 60,19 \\
& Total & 869 & 16,80 & 83,20 \\
\hline
\end{tabular}

Table 3. Percentage of Defects in $50 \mathrm{Kg}$ Packaged Sugar

\begin{tabular}{ccccccc}
\hline Code & Defect & $\begin{array}{c}\text { First } \\
\text { Period }\end{array}$ & $\begin{array}{c}\text { Second } \\
\text { Period }\end{array}$ & $\begin{array}{c}\text { Third } \\
\text { Period }\end{array}$ & $\begin{array}{c}\text { Fourth } \\
\text { Period }\end{array}$ & Total \\
\hline 1 & Torn Packaging & 37 & 39 & 30 & 40 & 146 \\
2 & Dirty Packaging & 103 & 78 & 54 & 64 & 299 \\
3 & Stitches Apart & 76 & 53 & 53 & 42 & 224 \\
4 & Less Bright Print & 64 & 63 & 39 & 34 & 200 \\
& Total & 280 & 233 & 176 & 180 & \\
\hline
\end{tabular}




\section{TiBuana}

Journal of applied Industrial Engineering-University of PGRI AdiBuana

DOI : https://doi.org/10.36456/tibuana.4.01.3174.28-35

From the table above, it is then applied to the Pareto diagram as follows:

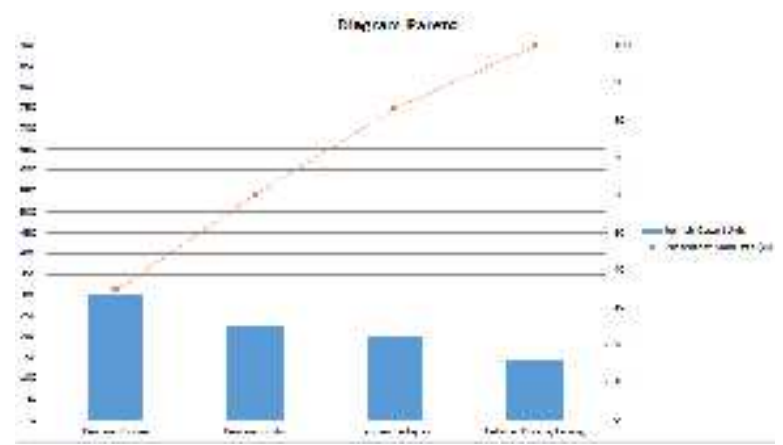

Figure 2. Pareto diagram of the number of defective types of granulated sugar products in $50 \mathrm{~kg}$ packages

c. Stratification Diagram

Stratification diagrams are used to group defect types of data into certain groups in order to show the source of the problem so that it can make conclusions easier. Because PG Kremboong uses a calculation of 1 period or the equivalent of 15 days, the stratification diagram uses calculations per period. d. Scatter Diagram

Scatter diagrams are used to determine the correlation between two variables, namely cause and effect, so that the points with the largest percentage of defects can be found. The following are the results of data processing using a scatter diagram:

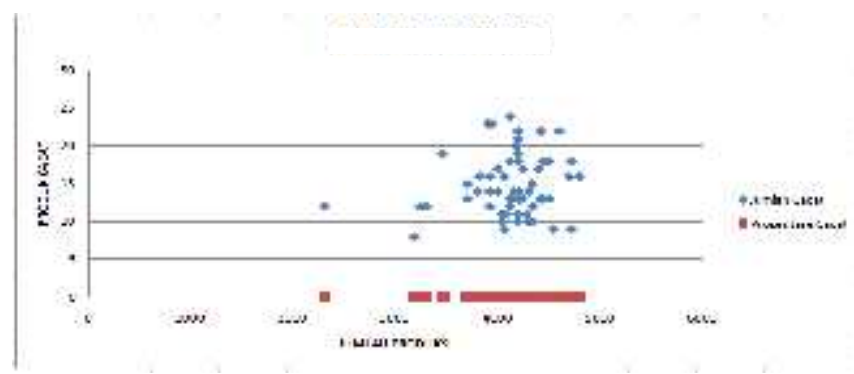

Figure 3: Scatter Diagram of the Percentage of Defects in $50 \mathrm{Kg}$ Packaged Sugar Products

e. Control Chart

Here is the data processing using the $\mathrm{P}$ control chart (proportion of defects) that is $100 \%$ inspected, so that the number of $n$ matches the amount of production per day.

Where:

Number of defects $=\sum$ defect $=869$ Total production $=\sum$ production $=$ 242980

(1) Proportion of Defects Calculation assumptions in the first data

$$
\mathrm{P}=\frac{D}{n}=\frac{1}{4}=0,026
$$

(2) Center Control Line (CL)

$$
\begin{aligned}
& C=\frac{\sum a}{\sum t p}= \\
& \frac{g}{2}=0,0035
\end{aligned}=
$$

(3) Lower Control Line (LCL)

Calculation assumptions in the first data 


\section{TiBuana}

Journal of applied Industrial Engineering-University of PGRI AdiBuana

DOI : https://doi.org/10.36456/tibuana.4.01.3174.28-35

LCL $=p-3 \sqrt{\frac{p(1-p)}{n}}=$
$0,0035-3 \sqrt{\frac{0,0(1-0,0)}{4}}=0,0007$

(4) Upper Control Line (UCL) Calculation assumptions in the first data

$$
\begin{aligned}
& U=p+3 \sqrt{\frac{p(1-p)}{n}} \\
& =0,0035 \\
& +3 \sqrt{\frac{0,0026(1-0,0026)}{4080}} \\
& =0,0063
\end{aligned}
$$

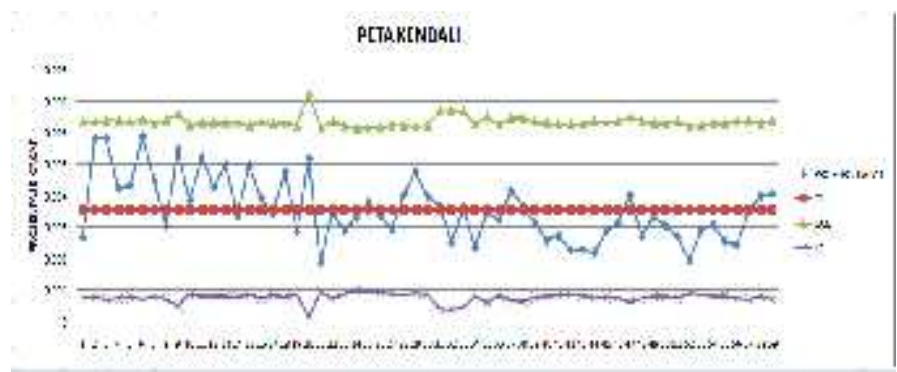

Figure 4.Control chart (control chart) of Percentage of Defects in Packaged Sugar Product 50

Based on data processing using control charts, the results show that the $6^{\text {th }}$ data is July 252018 , the number of production of 3900 units had the highest defect proportion value, namely 0.0058 with $L C L=0.0007$ and $\mathrm{UCL}=0.0064$. Meanwhile, the $21^{\mathrm{st}}$ data is August 11, 2018, the total production of 4720 units had the lowest defect proportion value, namely 0.0019 with $\mathrm{LCL}=0.0009$ and $\mathrm{UCL}=$ 0.0061 . f. Cause and Effect Diagram (Fishbone Diagram) Based on data processing using the Pareto diagram, it is known that torn packaging defects are the most dominant type of defect occurring. To determine the causes of torn packaging defects, data processing is carried out using a causal diagram (fishbone diagram) as follows: 


\section{TiBuana}

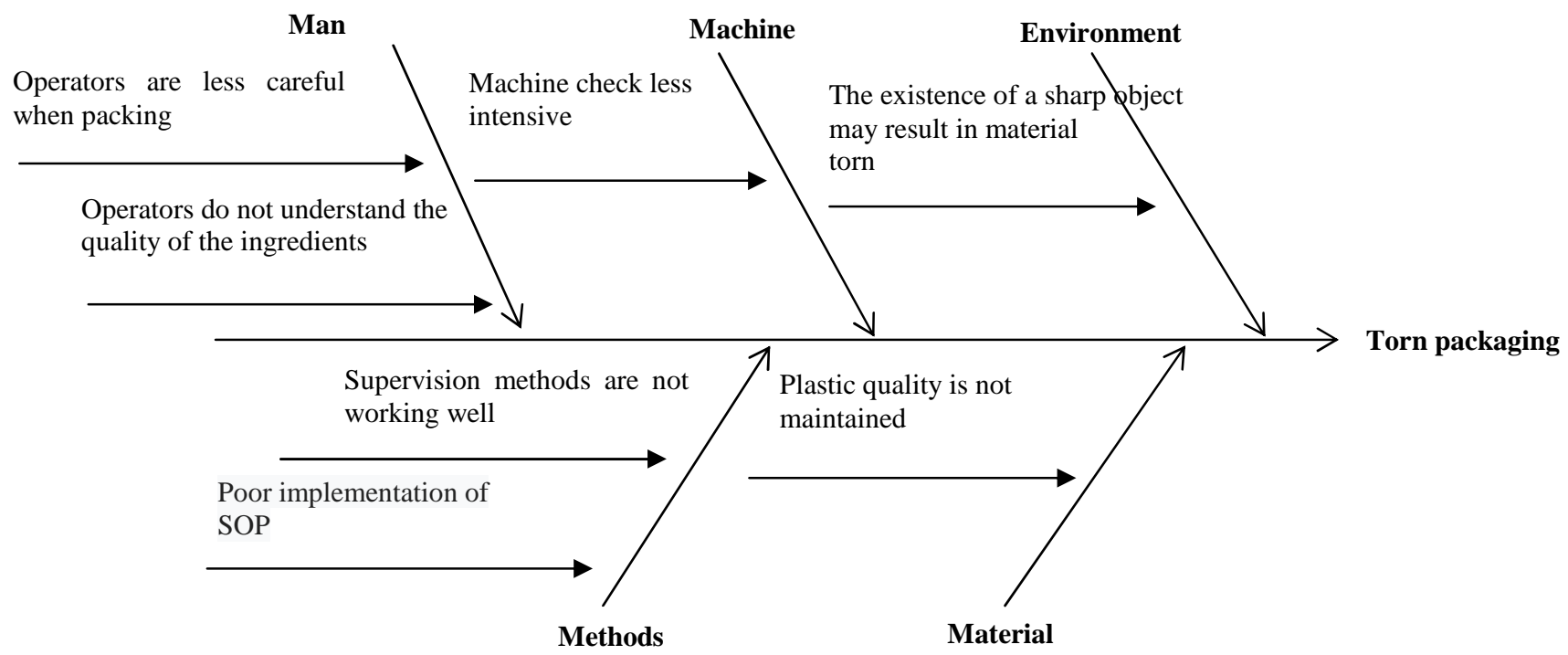

Figure 5. Fishbone Torn Packaging

Based on data processing using a fishbone diagram, it is known that torn packaging which is the most dominant type of defect is caused by several factors as follows:

a. Humans: operators are less careful when packing, operators do not understand the quality of materials

b. Machinery: less intensive machine checking

c. Environment: there are sharp objects that can cause the material to tear

d. Methods: the supervision method is not working well, the implementation of the SOP is not good

e. Material: plastic quality is not maintained

\section{CONCLUSION}

The following are the conclusions that have beenmade regarding defects that occur in granulated sugar products with a $50 \mathrm{~kg}$ package, as follows:

(1) Types of defects in granulated sugar with $50 \mathrm{Kg}$ packs that occurred at PG Kremboong in the period July September 2018 using Seven Tools were light printing (146), torn packaging (299), dirty packaging (224) and loose seams (200).
(2) Defects with torn packaging are the most dominant type of defect, using a fishbone diagram, it is known that there are several factors that cause defects with torn packaging in granulated sugar products, namely human factors, methods, machines, materials and environment.

(3) The recommended improvements to reduce the number of defects in the production of granulated sugar in 50 Kg packages are as follows:

a. Humans: operators need to be more careful and need training on good packaging standards

b. Machine: maintenance activities must be carried out according to a predetermined schedule and checks must be carried out correctly and on schedule

c. Environment: regularly checking and cleaning the environment

d. Methods: tighter supervision and carried out according to standards and socializing SOPs regularly

e. Material: emphasis on suppliers about quality standard. 


\section{REFERENCE}

1. Akshay Jaware, Komal Bhandare, Gaurav Sonawane, Shraddha Bhagat. (2018). Seven Quality Tools a Review. International Research Journal of Engineering and Technology (IRJET), volume: 05 Issue: 05, May 2018, pp. 27962798.

2. Damayanti, Subagyo, A R Wijaya and B Hartono. (2019). Seven Management and Planning Tools in Megaproject Management: A Literature Review. IOP Conf. Series: Materials Science and Engineering - Series 59 May 2009.

3. Deepak and Dheeraj Dhingra. (2016). Application of Quality Control Tools in a Bicycle Industry: A Case Study. IJRET: International Journal of Research in Engineering and Technology, volume: 05, Issue. 07, Jul-2016. pp. 119 - 127.

4. Lim Sanny and Ria Amalia. (2015). Quality Improvement Strategy to Defect Reduction with Seven Tools Method: Case in Food Field Company in Indonesia. International Business Management, vol. 9 (4), pp. $445-451$.

5. Luis Fonseca, Vanda Lima and Manuela Silva. (2015). Utilization of Quality Tools: Does Sector and Size Matter?.International Journal for Quality Research 9(4) 605-620.
6. Mirko Soković, Jelena Jovanović, Zdravko Krivokapić, Aleksandar Vujović. (2009). Basic Quality Tools in Continuous Improvement Process. Journal of Mechanical Engineering, vol. 55(5), pp. 333-341.

7. Neyestani, Behnam. (2017). Seven Basic Tools of Quality Control: An Appropriate Tools for Solving Quality Problems in the Organizations. MPRA - Munich Personal RePEc Archive, no. 77681.

8. Nur Hayati Rauf, Ahmad Padhil and Tri Nur Cholifah. (2020). Control Analysis of Sugar Packaging by Using of Seven Tools. Journal of Industrial Engineering Management, volume 2. No 2, pp. 80-89.

9. Sulaman Muhammad. (2015). Quality Improvement of Fan Manufacturing Industry by Using Basic Seven Tools of Quality: A Case Study. International Journal of Engineering Research and Applications, vol. 5, issue 4, ( Part -4) April 2015, pp. 30-35.

10. Varsha M. Magar and Vilas B. Shinde. (2014). Application of 7 Quality Control (7 QC) Tools for Continuous Improvement of Manufacturing Processes. International Journal of Engineering Research and General Science, volume 2, Issue 4, JuneJuly, 2014, pp. 364-371. 